\title{
METHOD OF ECODESIGN AND A NEW WAY OF Product DeVelopment
}

\author{
BAdida, M., VARgOVA, J., Hricova, B., Wessely, E.
}

Abstract: In the past, product have been designed and developed without considering its adverse impacts on the environment. Typical factors considered in product design included function, quality, cost, ergonomics and safety. However, no consideration was given specifically to the environmental aspects of a products throughout its entire life cycle. Product design and development relating to improved environmental performance has many expressions including design for environment, ecological design, environmental design, green design and life cycle design. The concept of ecodesign has been quickly and easily accepted by industry and many waste minimization and cleaner production programs have been introduced over the last decade.

Key words: environment, ecodesign, product, life cycle assessment
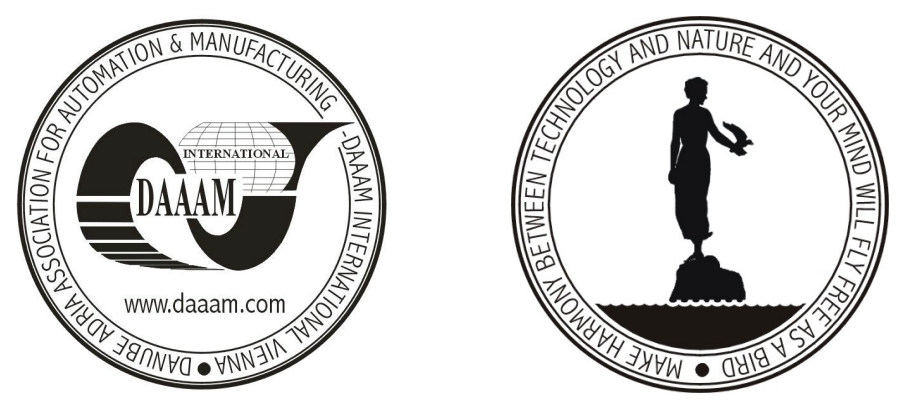

Authors' data: Prof. PhD. Eng. Badida M.[iroslav], PhD. Eng. Vargova J.[ana], Eng. Hricova B.[eata], doc. PhD. ing. Wessely E.[mil],Technical University of Kosice, Faculty of Mechanical Engineering, Letna 9, Kosice 041 87, Slovakia, miroslav.badida@tuke.sk,jana.vargova@tuke.sk,emil.wessely@tuke.sk

This Publication has to be referred as: Badida, M., Vargova, J., Hricova, B., Wessely, E. (2006). Method of Ecodesign and a New Way of Product Development, Chapter 02 in DAAAM International Scientific Book 2006, B. Katalinic (Ed.), Published by DAAAM International, ISBN 3-901509-47-X, ISSN 1726-9687, Vienna, Austria

DOI: $10.2507 /$ daaam.scibook.2006.02 